\title{
Gelatinous Specimen
}

National Cancer Institute

\section{Source}

National Cancer Institute. Gelatinous Specimen. NCI Thesaurus. Code C135503.

A specimen that has a gelatinous consistency. 